\title{
Planktonic carbon and nitrogen cycling off northwest Spain: variations in production of particulate and dissolved organic pools
}

\author{
Antonio Bode ${ }^{1, *}$, Marta M. Varela ${ }^{1}$, Eva Teira ${ }^{2}$, Emilio Fernández $^{2}$, \\ Nicolás González ${ }^{1}$, Manuel Varela ${ }^{1}$ \\ ${ }^{1}$ Instituto Español de Oceanografía, Centro Oceanográfico de A Coruña, Apartado 130, 15080 A Coruña, Spain \\ ${ }^{2}$ Departamiento de Biología Animal y Ecología, Facultad de Ciencias, Campus Lagoas-Marcosende s/n, Universidad de Vigo, \\ Vigo, Spain
}

\begin{abstract}
The coupling of carbon and nitrogen fluxes between dissolved and particulate organic pools was examined at a coastal location off Galicia (northwest Spain). Monthly measurements of dissolved and particulate carbon and nitrogen stocks, along with inorganic carbon and nitrogen uptake and release of dissolved organic substances were obtained between October 1998 and September 1999. Carbon fluxes were determined using incubations of plankton with inorganic ${ }^{14} \mathrm{C}$ and nitrogen fluxes were determined using incubations of plankton with ${ }^{15} \mathrm{~N}$-ammonium. Dissolved organic carbon (DOC) was often released near the surface, while maximum release of dissolved organic nitrogen (DON) generally occurred near the base of the euphotic zone. Both rates were linearly related to the corresponding uptake rates; however, the percentages of extracellular release relative to total uptake (PER) were highest during low-productivity periods, when both carbon and nitrogen PER exceeded $50 \%$ in deep layers. PER values were generally below $20 \%$ near the surface. Despite max-

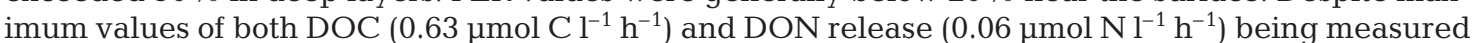
during spring and summer, volumetric values of both rates were not significantly correlated through the year. Such a differential behaviour caused a mismatch between DOC:DON release ratios and the $\mathrm{C}: \mathrm{N}$ ratios of seston at discrete depths. In contrast, euphotic-zone integrated release rates showed average DOC:DON ratios reflecting the C:N ratios of seston. These results suggest that most of the organic matter available for microbial plankton near the coast derives from phytoplankton, which in turn is sustained by a rapid recycling of organic matter when external nutrient inputs are reduced.
\end{abstract}

KEY WORDS: Dissolved organic matter $\cdot$ DOC $\cdot$ DON $\cdot$ Uptake $\cdot$ Release $\cdot$ Coastal $\cdot$ Primary production

\section{INTRODUCTION}

The fate of primary production in aquatic systems is generally analysed as the contribution of particulate matter to sustain food webs or as a source of sediments (e.g. Berger et al. 1989, Legendre \& Le Fèvre 1995). However, there is growing evidence that a significant fraction of the gross primary production is released as dissolved organic matter (DOM), thus increasing the amount of organic matter that is available for export to sediments and for fuelling food webs (Legendre \& Le
Fèvre 1995, Williams 1995, Nagata 2000, Carlson 2002). More than $90 \%$ of organic carbon in the oceans is in dissolved form, although only a small fraction can be considered as labile, i.e. available for ready assimilation by heterotrophic bacteria or even by phytoplankton (Ogawa \& Tanoue 2003).

Most studies of DOM in the upper ocean have concentrated on the release of dissolved organic carbon (DOC) from primary producers, either through the quantification of stocks (Williams 1995, Doval et al. 1997, 1999, Alvarez-Salgado et al. 1999, 2001, Vidal 
et al. 1999) or by measuring the release of recent photosynthates in experimental incubations of plankton with ${ }^{14} \mathrm{C}$ (e.g. Teira et al. 2001a,b, 2003a,b, Morán et al. 2002a,b). The latter revealed rates of DOC release occurring at time scales of hours, which suggest a close interaction between production and consumption of organic matter in the microbial food web. Comparatively, there are fewer studies on the rates of release of dissolved organic nitrogen (DON) by natural planktonic communities using the tracer ${ }^{15} \mathrm{~N}$ (see Bronk 2002 for a review), and a controversy exists on the magnitude of this flux in the ocean (Slawyk et al. 1998, 2000, Bronk \& Ward 2000, Hasegawa et al. 2000a,b, Varela et al. 2003b). Besides the specific complexity of experimentally measuring uptake and DON release rates using ${ }^{15} \mathrm{~N}$, which is greater than that for measuring DOC release with ${ }^{14} \mathrm{C}$ (e.g. Bronk \& Glibert 1991, Slawyk \& Raimbault 1995, Slawyk et al. 1998), estimations of the former rate are complicated by the fact that phytoplankton can take up a variety of nitrogen sources (both organic and inorganic) from which a fraction is released as DON at time-scales equivalent to the time interval employed for the measurement. A complete assessment of DON release must ideally include experimental incubations of plankton with several $\mathrm{N}$ sources, but to date few studies provided such information (Bronk 2002).

An excess of DOC relative to DON is characteristic of DOM stocks, with C:N molar ratio values generally above 15 (Williams 1995, Doval et al. 1997, 1999, Alvarez-Salgado et al. 1999, 2001, Vidal et al. 1999, Bronk 2002, Carlson 2002). The mean turnover time of such stocks in the ocean varies from months to years (e.g. Alvarez-Salgado et al. 1999, Vidal et al. 1999). As nitrogen is often a limiting nutrient for both phytoplankton and bacterial production (e.g. Glibert 1988, Kirchman 2000), the conservation of nitrogen within planktonic food webs through remineralisation and direct uptake of DON can be expected. This preferential use of DON would cause the increase of $\mathrm{C}: \mathrm{N}$ ratios of DOM with time (Ogawa \& Tanoue 2003). Amino acids and urea are among the DON compounds readily consumed by bacteria and phytoplankton (Kirchman 2000). Conversely, freshly released DOM from planktonic organisms, either by direct exudation or mediated by grazing (Nagata 2000, Carlson 2002), would be expected to contain a larger fraction of labile compounds than aged DOM. Moreover, if DOM is released by cell breaking, as through lysis (Agustí et al. 1998) or zooplankton sloppy feeding (Hasegawa et al. 2000b), it can be expected that its composition would be similar to that of the intact cells, with a C:N ratio close to the Redfield value (Redfield et al. 1963). However, only few studies allowed for a comparison of DOC and DON release in natural plankton communi- ties and the results showed either low C:N values because of DON accumulation (Bronk et al. 1998) or a low correlation between both release rates and high variability in C:N ratios (Varela et al. 2003b). Therefore, from these previous data it appears that DOC and DON release fluxes are generally uncoupled at both short and long time scales.

Oligotrophic areas, such as the central gyres of the Atlantic Ocean (Teira et al. 2001b, 2003a), exhibit low absolute rates of DOC release but these values indicate notably high fraction of total primary production. In contrast, DOC and DON release in productive areas, such as upwelling sites (Teira et al. 2001a, Morán et al. 2002a,b, Varela et al. 2003b) can reach high absolute values but they often represent a relatively small fraction of total primary production. Experimental studies showed that the release of DOC generally varies linearly with total primary production (Teira et al. 2001a,b, Morán et al. 2002a,b, Teira et al. 2003b), but there are no equivalent studies for DON release.

Previous studies in the upwelling area off Galicia (northwest Spain) found high concentrations of DOC and DON, notably near the coast (Doval et al. 1997, 1999, Alvarez-Salgado et al. 1999, 2001, Bode et al. 2001, Varela et al. 2003a,b). Short-term DOC release rates are high during phytoplankton blooms, as those caused by the upwelling between March and October (Teira et al. 2001a, Morán et al. 2002a,b, Teira et al. 2003b), and the same occurs with DON release (Varela et al. 2003b). Such release, along with relatively low bacterial uptake rates (Barbosa et al. 2001, Morán et al. 2002a, Valencia et al. 2003, Varela et al. 2003a), produce accumulations of DOM, which reach a maximum at the end of summer. Offshore export by hydrographic mechanisms (e.g. Alvarez-Salgado et al. 2001) and enhanced bacterial consumption of organic substrates at the end of summer (Teira et al. 2003b, Valencia et al. 2003, Varela et al. 2003a) return DOM concentrations in the water column to annual minimum values, similar to those found during winter.

In this study we examined monthly measurements of short-term (hourly) particulate organic matter production rates and dissolved organic matter release rates. The objective is to determine the coupling between carbon and nitrogen cycling at short time-scales through the plankton at a coastal location off northwest Spain (northeast Atlantic). Previous studies described the influence of the seasonal variability of the coastal upwelling on oceanographic conditions, nutrients, and plankton biomass, taxonomic composition, and production at this site (Casas et al. 1997, 1999, Bode et al. 1998, 2004, Valencia et al. 2003). In addition, Teira et al. (2003b) provided an analysis of the organic carbon fluxes, including bacteria, DOC and sinking particles. 


\section{MATERIALS AND METHODS}

Sampling. Samples of plankton were collected at a shelf station off A Coruña (Galicia, northwest Spain) at approximately monthly intervals, from October 1998 to September 1999 (Fig. 1). The maximum depth of the station was $80 \mathrm{~m}$. At each sampling date, vertical profiles of temperature, salinity, chlorophyll-fluorescence and photosynthetically available irradiance (PAR) were obtained with a Seabird SBE-25 CTD equipped with a Seapoint in situ fluorometer and a LiCOR spherical PAR sensor. Water from up to 5 levels, corresponding to optical depths of $100,50,25,10$ and $1 \%$ of surface PAR $\left(E_{0}\right)$, was sampled with 51 Niskin bottles deployed immediately after the CTD casts.

Phytoplankton biomass was estimated at 5 depths from chlorophyll a (chl a) concentrations determined from acetonic extracts of plankton retained by Whatman GF/F filters and measured by the fluorimetric method (Parsons et al. 1984). Concentrations of particulate organic carbon (POC) and nitrogen (PON) were also determined at 5 depths in seston collected by filtering $500 \mathrm{ml}$ of water through Whatman GF/F filters, subsequently dried $\left(60^{\circ} \mathrm{C}\right)$ and analysed in a Perkin Elmer CHN Elemental Analyser.

Carbon uptake and release. Organic carbon dynamics were determined from incubations of plankton with ${ }^{14} \mathrm{C}$-labelled bicarbonate, which allowed for the simultaneous determination of production rates of particulate organic carbon (PPOC) and release of dissolved organic carbon (rDOC). Four $30 \mathrm{ml}$ seawater samples were collected from 3 selected depths, corresponding to irradiance levels of 100, 10 and $1 \%$ of surface PAR. Each bottle was inoculated with $740 \mathrm{kBq}(20 \mu \mathrm{Ci})$ of $\mathrm{NaH}_{14} \mathrm{CO}_{3}$ and then incubated onshore for $2 \mathrm{~h}$ in an incubator that simulated the irradiance experienced by the cells at the original sampling depths. Incubation bottles were cooled by pumping surface seawater around them. After the incubation, two $7 \mathrm{ml}$ subsamples were drawn from each bottle and filtered through $0.2 \mu \mathrm{m}$ polycarbonate membrane filters. Labelled dissolved inorganic carbon was removed by acidifying the filtrates with $40 \mathrm{\mu l}$ of $50 \% \mathrm{HCl}$ and bubbling with $\mathrm{CO}_{2}$ free air for $12 \mathrm{~h}$. Scintillation cocktail was then added to the filtrates and the radioactivity measured with a LKB $\beta$-scintillation counter. Quenching corrections were made using an external standard. Duplicate blank tests were run in parallel by inoculating and immediately processing $0.2 \mu \mathrm{m}$ filtered seawater in the same way as mentioned above. The contribution of rDOC to total carbon uptake (PPOC + rDOC) was expressed as percentage of extracellular carbon release $\left(\mathrm{PER}_{\mathrm{DOC}}=\right.$ $100 \mathrm{rDOC} /[\mathrm{PPOC}+\mathrm{rDOC}])$. More detailed descriptions of PPOC and rDOC through the water column during the study period can be found in Valencia et al. (2003) and Teira et al. (2003b).

Nitrogen uptake and release. Uptake of nitrogen was measured from incubations of plankton with ${ }^{15} \mathrm{~N}$ labelled ammonium, which provided estimations of production of particulate organic nitrogen $\left(\rho \mathrm{NH}_{4}{ }^{+}\right)$and release of dissolved organic nitrogen (rDON). Ammonium was chosen from all the potentially available inorganic nitrogen sources (nitrate, nitrite and ammonium) because it was the source most used by phytoplankton over the year in the northwest Spanish shelf (e.g. Alvarez-Salgado et al. 2002, Bode et al. 2004), despite the occasional inputs of nitrate by the seasonal upwelling. Samples were collected from the same optical depth levels as those for carbon incubations. Water from each depth was distributed into duplicate $250 \mathrm{ml}$ acid-cleaned polycarbonate bottles. Each sample was labelled with $0.1 \mu \mathrm{M}$ of $\left({ }^{15} \mathrm{NH}_{4}\right)_{2} \mathrm{SO}_{4}$ and then incubated for 2 to $3 \mathrm{~h}$ as described for carbon. Incubations of plankton over such intervals produce reliable rate estimates that avoid overestimates due to surge uptake and underestimates due to isotopic equilibrium between extracellular and intracellular pools (Glibert 1988, Bronk \& Glibert 1991). Average $( \pm$ SE) initial atom percent enrichment in the incubation bottles was

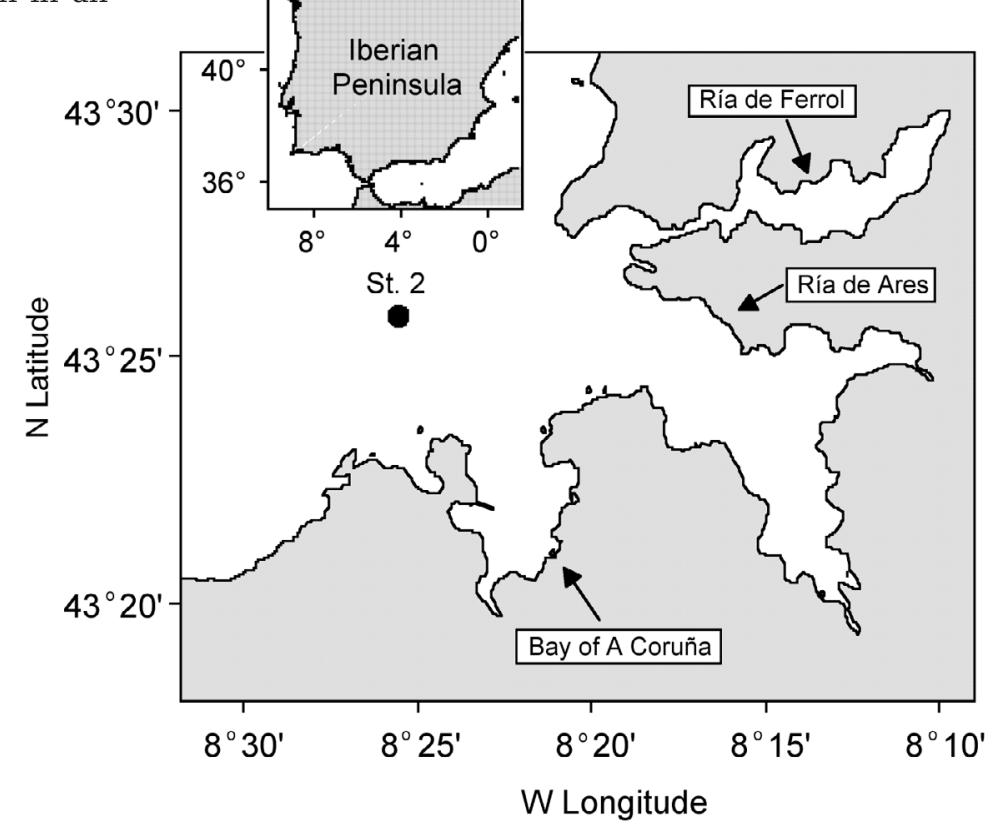


$26.6 \pm 2.2 \%(n=60)$. After the incubation period, samples were processed using the method of Slawyk et al. (1998). Particulate nitrogen was retained by Whatman GF/F filters, the filtrate was collected and stored frozen until further determination of dissolved inorganic nitrogen (DIN), DON concentrations, and ${ }^{15} \mathrm{~N}$ enrichment. Concentrations of particulate nitrogen and ${ }^{15} \mathrm{~N}$ content were measured in the particles retained by the filter. Also, initial nitrogen concentrations in both particulate and dissolved phases, along with ${ }^{15} \mathrm{~N}$ enrichment, were determined in aliquots inoculated with ${ }^{15} \mathrm{~N}$ and filtered immediately without incubation.

Determinations of $\mathrm{NO}_{3}{ }^{-}, \mathrm{NO}_{2}{ }^{-}$and $\mathrm{NH}_{4}{ }^{+}$concentrations were carried out by using air-segmented-flow and colorimetric techniques, with a Technicon Autoanalyzer II (Grasshoff et al. 1983). The determinations of DON were carried out using the persulfate oxidation method as described in Slawyk \& Raimbault (1995) and Slawyk et al. (1998). Enrichment of ${ }^{15} \mathrm{~N}$ of dissolved and particulate organic matter was determined using an
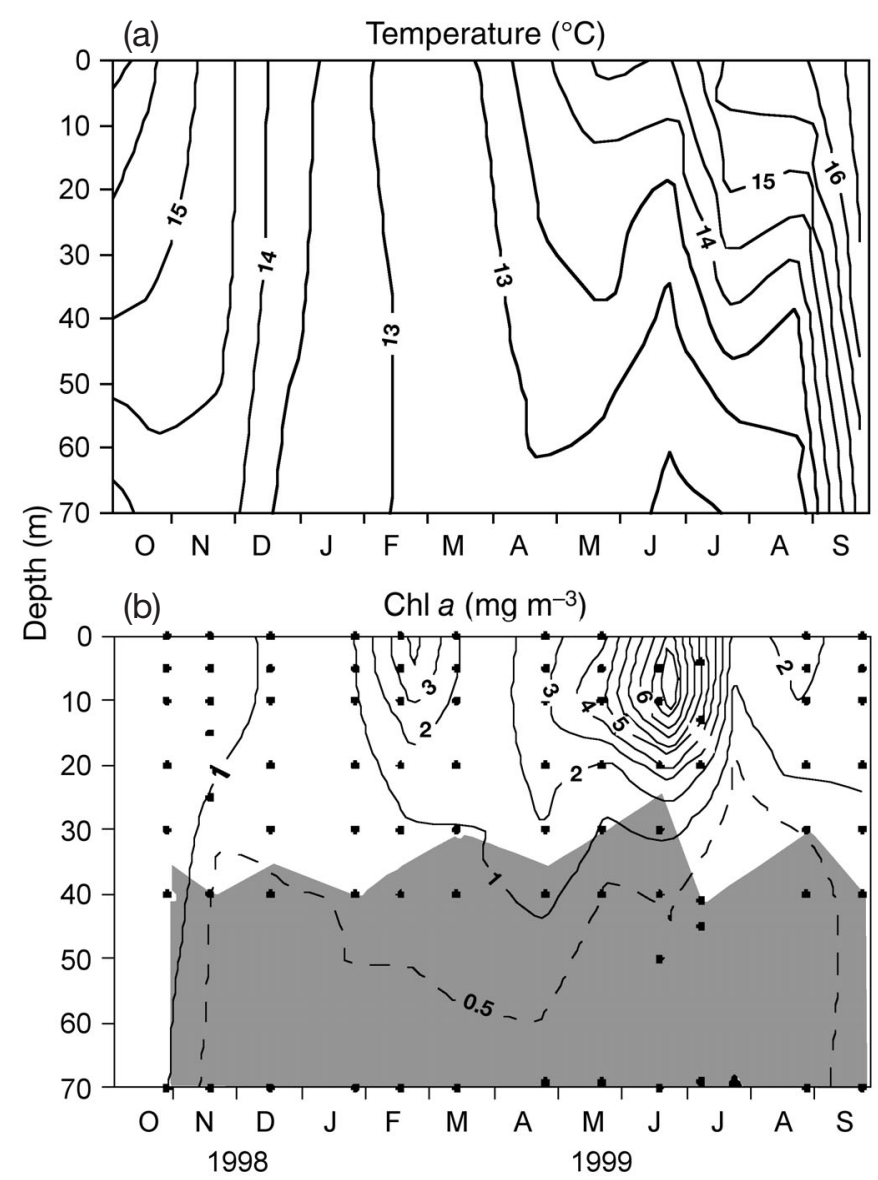

Fig. 2. Variations of (a) temperature and (b) chl a concentration in the water column during the study. Discrete sampling depths are indicated by dots, and the water layer receiving $<1 \%$ of surface irradiance is indicated by shading (b) isotope-ratio mass spectrometer (Thermo Finnigan Mat Delta Plus). Filters with particulate matter were dried at $50^{\circ} \mathrm{C}$ before analysis, while DON and DIN were adsorbed on glass-fibre filters by previous conversion of all nitrogen forms into $\mathrm{NH}_{4}{ }^{+}$as described in Slawyk \& Raimbault (1995), then dried and analysed the same way as the filters with particles. The coefficient of variation of nitrogen concentration or ${ }^{15} \mathrm{~N}$ atom-percent enrichment values of the 2 replicate bottles was generally $<20 \%$. As with rDOC, the contribution of rDON to total ammonium uptake $\left(\rho \mathrm{NH}_{4}{ }^{+}+\mathrm{rDON}\right)$ was expressed as percentage of extracellular nitrogen release $\left(\mathrm{PER}_{\mathrm{DON}}=\right.$ $100 \mathrm{rDON} /\left[\left(\rho \mathrm{NH}_{4}{ }^{+}+\mathrm{rDON}\right]\right)$.

Statistical analysis. Relationships between the measured rates and concentrations were analysed by regression. Rates (in mmol m $\mathrm{m}^{-3} \mathrm{~h}^{-1}$ or mmol m $\mathrm{m}^{-2} \mathrm{~h}^{-1}$ ) were log-transformed to normalise data. Model II regression (Sokal \& Rohlf 1981) was used as both the compared variables were subject to error. However, Model I (least squares regression) was also calculated to provide equations for the estimation of missing values (e.g. rDOC from PPOC). A similar procedure was employed by Teira et al. (2001a,b, 2003b) in the study of PPOC and rDOC relationships. In addition, C:N ratios for euphotic-zone integrated uptake or release rates were computed as the slope of the linear regression relating the corresponding rates. In this case, the regression line was forced through the origin, as the intercept has no biological meaning.

\section{RESULTS}

\section{Oceanographic conditions and phytoplankton}

Most of the hydrographic variability observed can be explained using the vertical distribution of temperature (Fig. 2). The seasonal thermal cycle induced the main changes in the water column, which was well mixed during winter and which was progressively stratified during spring and summer because of the heating of the surface. This cycle is interrupted by upwelling and downwelling phenomena characteristic of this region (e.g. Casas et al. 1997). Upwelling events, as in June and August 1999, introduced deep and cold waters near the surface. Downwelling of surface waters, caused by the accumulation of shelf waters towards the coast, was often observed at the end of summer, as in September 1999. More details on the hydrographic conditions during the sampling period covered by this study can be found in Valencia et al. (2003) and Teira et al. (2003b).

Phytoplankton blooms, indicated by high chlorophyll a concentrations (Fig. 2b), were found in early spring (February to March 1998), and during most of 

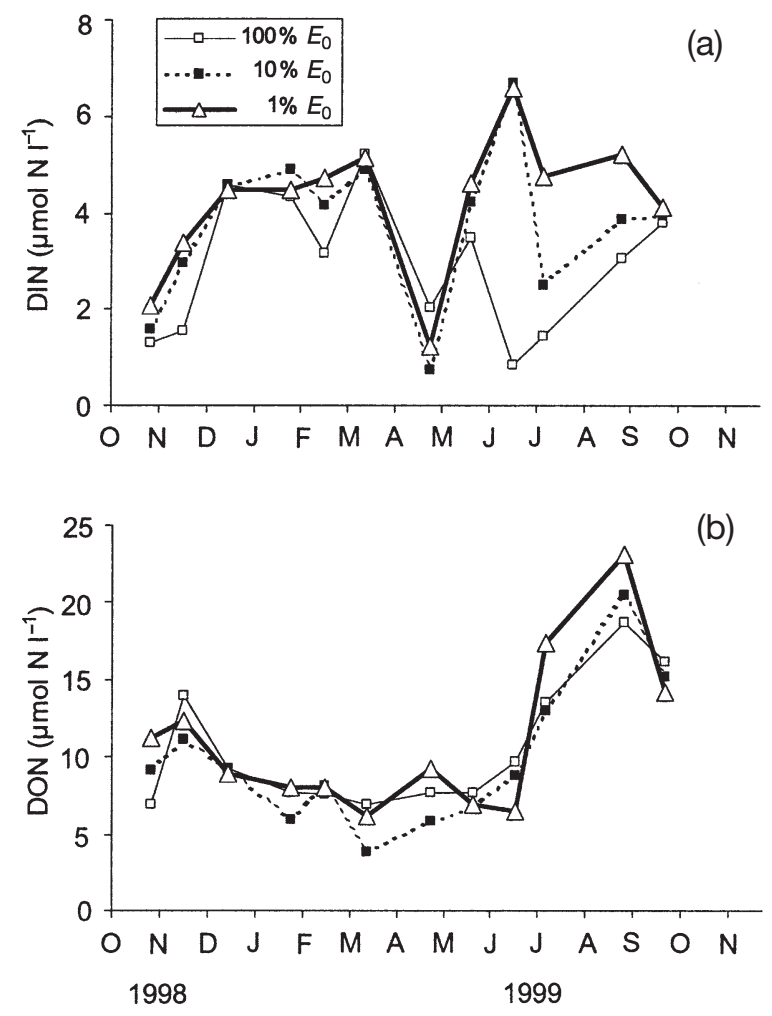

Fig. 3. Variations in the concentrations of (a) dissolved inorganic nitrogen (DIN) and (b) dissolved organic nitrogen (DON) during the study. $E_{0}$ : surface PAR

summer, the latter mainly due to upwelling events. Maximum chlorophyll values were always found near the surface ( 0 to $10 \mathrm{~m}$ depth) although the mean $( \pm \mathrm{SE})$ depth of the euphotic layer was $35.0 \pm 0.2 \mathrm{~m}$.

Inorganic nitrogen was never exhausted in the euphotic layer (Fig. 3a). Nitrate ranged between 0.10 and $6.22 \mu \mathrm{M}$ and ammonium between 0.10 and $1.02 \mu \mathrm{M}$. The highest values were reached at the base of the euphotic layer during upwelling events (e.g. June 1999), when maximum differences between the concentration values at the surface and at the bottom were found. The frequent mixing of the water column during most of the year caused DIN to generally exceed $1 \mu \mathrm{mol} \mathrm{l}^{-1}$ throughout the euphotic layer. Other inorganic nutrients, as phosphate or silicate, followed a seasonal cycle similar to DIN (Casas et al. 1997, Bode et al. 2004).

In contrast to DIN, dissolved organic nitrogen concentrations were rather constant for most of the year, but increased rapidly during late spring and summer (Fig. 3b). It can be expected that dissolved organic carbon concentrations, although not measured during this study, followed a pattern similar to that of DON. Varela et al. (2003a) had previously shown the accumulation of DOC in waters of the nearby Ria de Ferrol between winter and late summer.

\section{$\mathrm{C}$ and $\mathrm{N}$ uptake and release}

Variations in PPOC (Fig. 4a) followed those of chlorophyll. Maximum values were found generally at the surface and during blooms, with the highest value in June 1999. Release of DOC varied similar to that of PPOC, with maximum values at blooms, but in this case with a vertical distribution different from that of PPOC (Fig. 4b). Values of surface rDOC were generally equivalent to those measured at intermediate depths (10\% of surface PAR), with the exception of the values measured in June 1999 (when rDOC at the surface exceeded by an order of magnitude rDOC at the
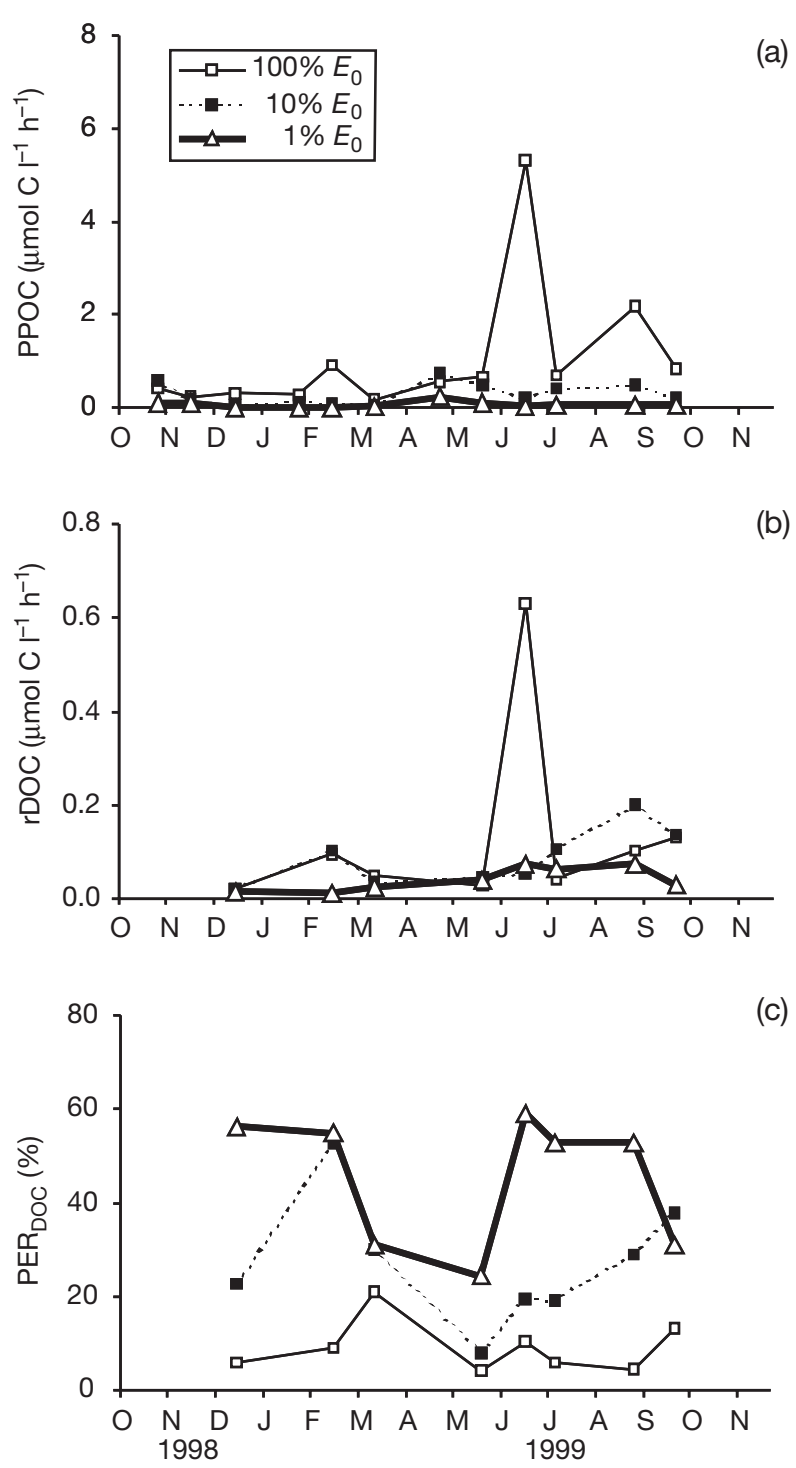

Fig. 4. Variations of (a) particulate organic carbon incorporation (PPOC), (b) dissolved organic carbon release (rDOC) and (c) percentage of recently incorporated carbon released as DOC $\left(\mathrm{PER}_{\mathrm{DOC}}\right)$ during the study. $E_{0}$ : surface PAR 

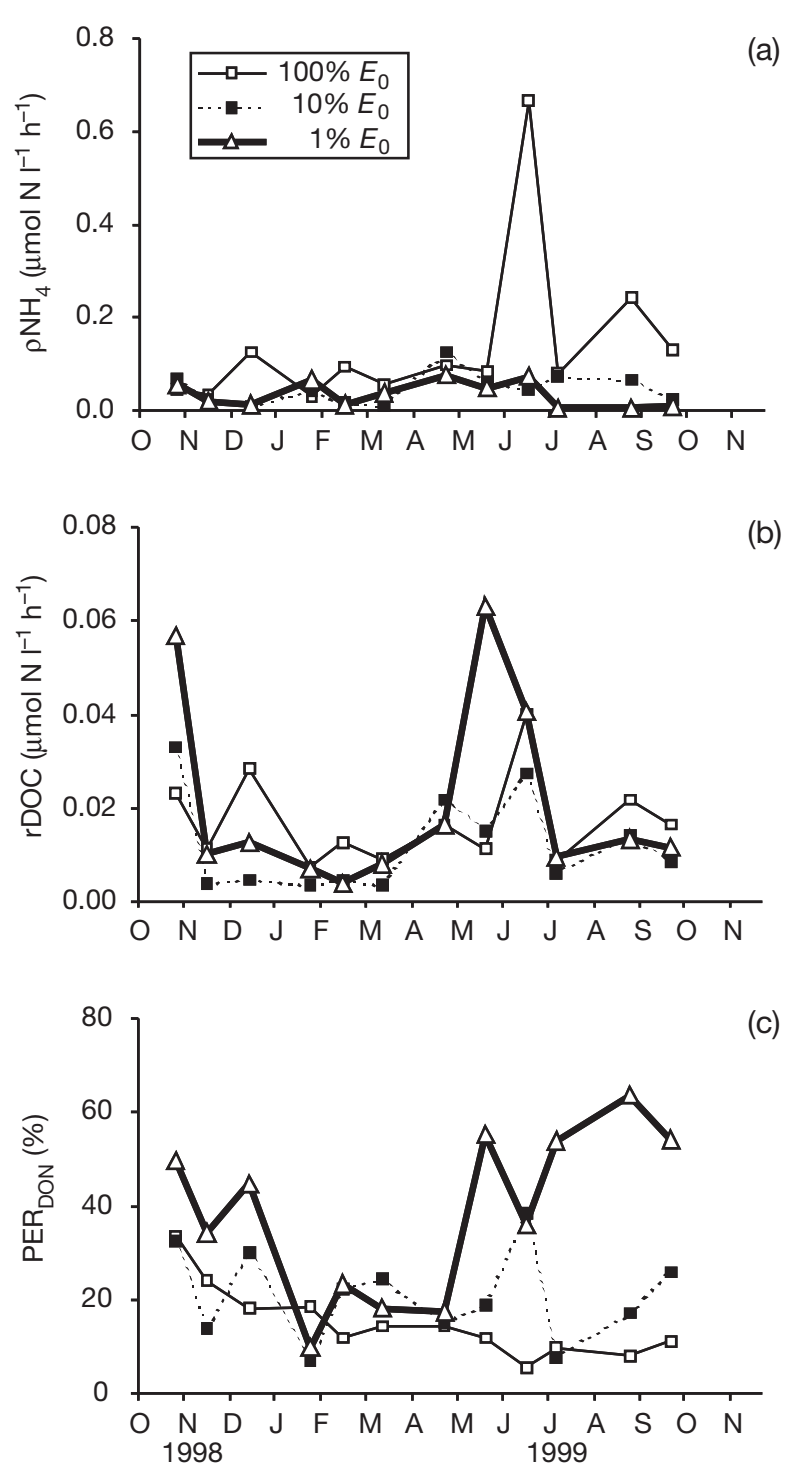

Fig. 5. Variations of (a) ammonium uptake $\left(\mathrm{\rho NH}_{4}\right)$, (b) release of dissolved organic nitrogen (rDON) and (c) percentage of recently incorporated nitrogen released as $\mathrm{DON}\left(\mathrm{PER}_{\mathrm{DON}}\right)$ during the study. $E_{0}$ : surface PAR

other sampling depths). As described by Teira et al. (2003), rDOC was not a constant fraction of total carbon uptake, with $\mathrm{PER}_{\mathrm{DOC}}$ exceeding $50 \%$ during winter but also in most summer samples (Fig. 4c). Maximum $\mathrm{PER}_{\mathrm{C}}$ were mostly found at the bottom of the euphotic layer, while values at the surface were $<20 \%$.

High values of $\mathrm{\rho NH}_{4}$ were found in conjunction with maxima in PPOC, particularly those observed in summer at the surface (Fig. 5a). As with PPOC, values for surface samples were generally higher than those for the bottom of the euphotic layer. However, the distribution of rDON values followed a different pattern
(Fig. 5b). Maximum rDON values appeared in periods of low PPOC and chlorophyll, as in November 1998 and May 1999. Correspondingly, $\mathrm{PER}_{\mathrm{DON}}$ exceeded $50 \%$ of total ammonium uptake at these maxima but values remained high for most of the summer, particularly at the bottom of the euphotic layer (Fig. 5c). The lowest $P E R_{D O N}$ values of the water-column were generally found at the surface, where a decrease was observed between late autumn and early summer.

The coupling between $\mathrm{C}$ and $\mathrm{N}$ uptake or release, displayed by the variability of the corresponding $C: N$ ratios, was often low (Fig. 6). While C:N values of seston were close to the value of the molar Redfield ratio (6.6, Redfield et al. 1963) both C:N uptake and release
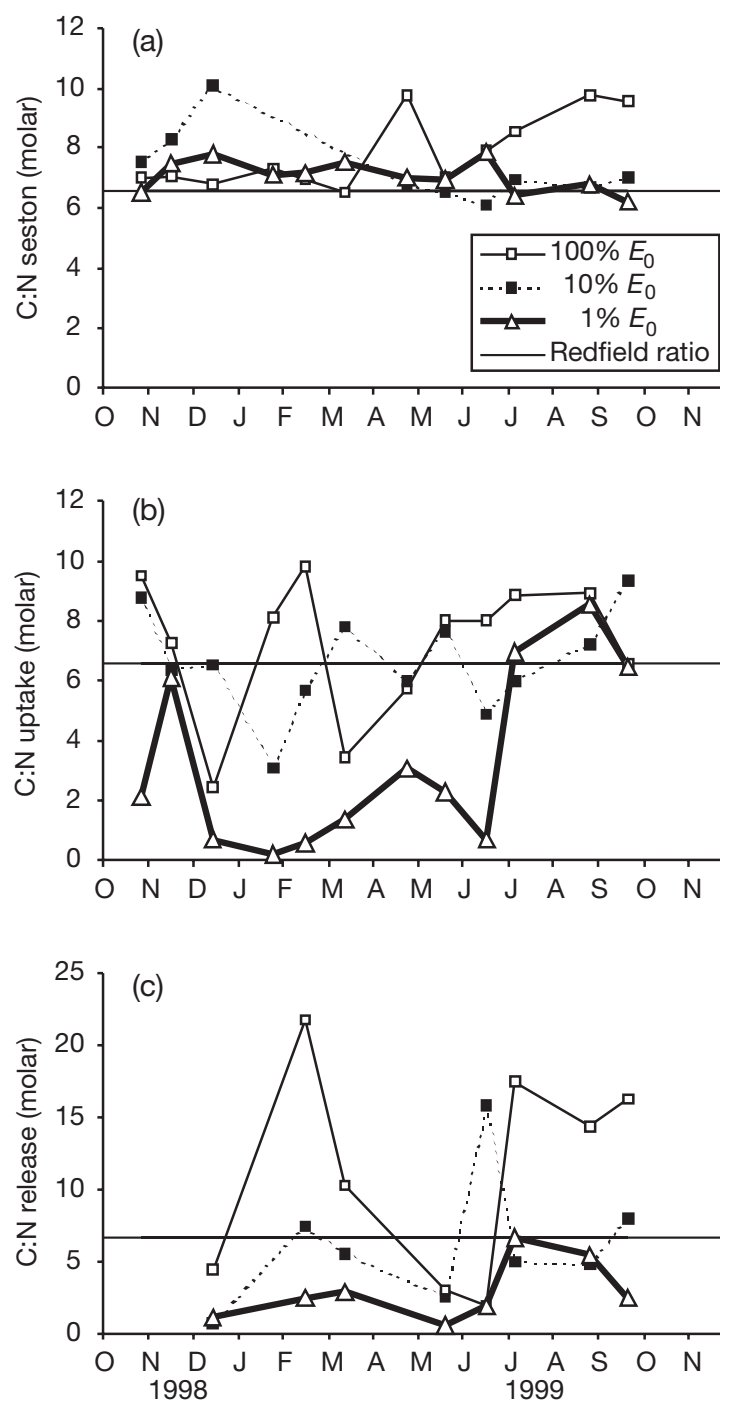

Fig. 6. Variations of C:N ratios of (a) seston, (b) uptake rates and (c) dissolved organic matter release rates during the study. Continuous line indicates the Redfield value $(6.6 \mathrm{~mol} \mathrm{C}$ $[\mathrm{mol} \mathrm{N}]^{-1}$ ). $E_{0}$ : surface PAR 
rates at single depths were generally far from this value. The bottom of the euphotic layer showed a relative deficit of carbon uptake for most of the year, but especially during winter and spring. In contrast, a relative excess of carbon uptake was observed at the surface at nearly every sampling date. The maximum deviation from the Redfield value was observed for the $\mathrm{C}: \mathrm{N}$ of release rates (Fig. 6c). In this case, the excess of carbon release at the surface reached values equivalent to 3-fold the Redfield value during phytoplankton blooms in February 1998 and July 1999. As with uptake rates, there was a relative excess of rDON near the bottom of the euphotic zone.

\section{Relationships between release of DOC or DON and uptake rates}

Both DOC and DON release rates were significantly correlated with chlorophyll $a$ and the corresponding uptake rates (Table $1 \&$ Fig. 7). In addition, log-log regressions allowed for the estimation of release rates from other variables when the former were not determined, as shown by Teira et al. (2001a). Nevertheless, determination coefficients were generally $<0.5$ and, therefore, the resulting estimates must be viewed with caution. Interestingly, a significant regression line can be computed between rDON and chlorophyll or PPOC but not between rDON and PON. This suggests that the release of DON depends mainly on phytoplankton.

The release of DOC was not a constant fraction of PPOC, as the value of the slope of the regression line $\left(b^{\prime}\right)$ was lower than 1 (upper 95\% confidence limit for $b^{\prime}$ was $<1$ ). Also, there was no significant correlation between $\mathrm{rDOC}$ and rDON but these release rates were linearly related when PER values were compared (Fig. $7 \mathrm{C}$ ). The value of the slope of the regression line between $\mathrm{PER}_{\mathrm{DOC}}$ and $\mathrm{PER}_{\mathrm{DON}}$ was close to 1 (lower and upper $95 \%$ confidence limits were 0.786 and 1.372),
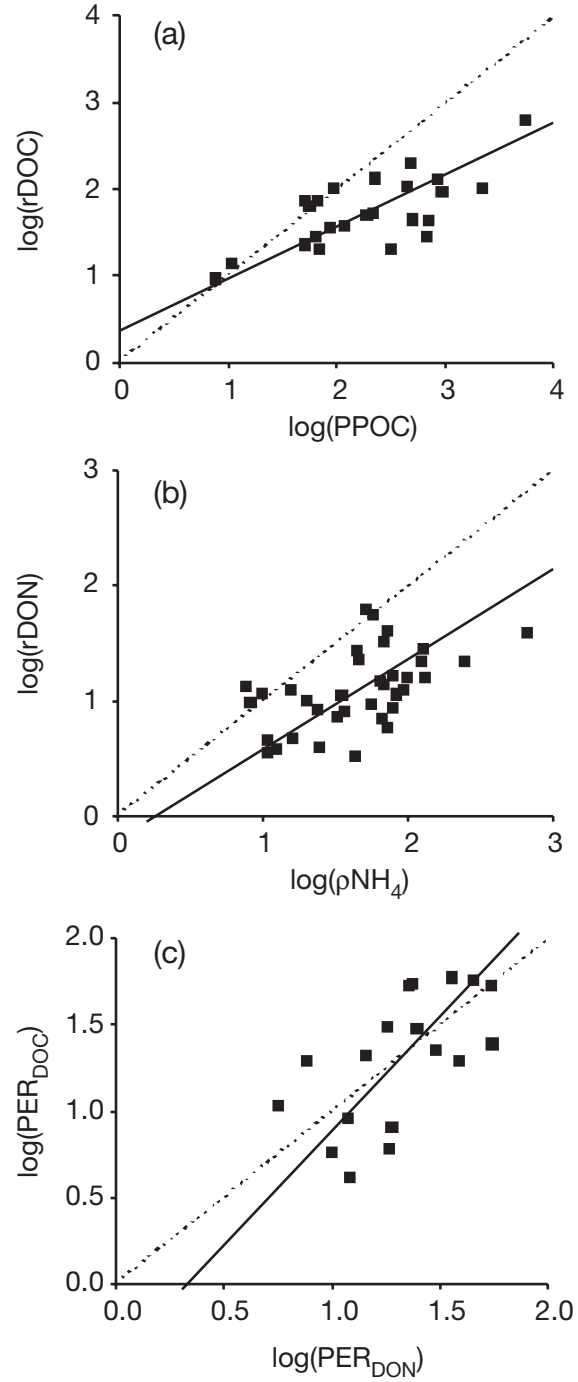

Fig. 7. Relationships between (a) $\log (\mathrm{rDOC})$ and $\log (\mathrm{PPOC})$, (b) $\log (\mathrm{rDON})$ and $\log \left(\mathrm{NNH}_{4}\right)$, and (c) $\log \left(\mathrm{PER}_{\mathrm{DOC}}\right)$ and

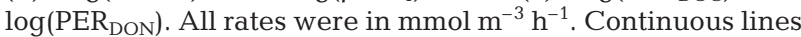
indicate the significant Model II regression in each panel (see Table 1). Dashed lines indicate the 1:1 relationship

Table 1. Parameters of regression lines between log-transformed rDOC or rDON and other variables using volumetric values. Equations were computed using both Model I and Model II regression models (Sokal \& Rohlf 1981): $y=a+b x$. $b^{\prime}:$ slope of Model II regression. $x$ : independent variable. $y$ : independent variable. $\mathrm{SE}_{a}$ and $\mathrm{SE}_{b}$ : standard error of the coefficients $a$ and $b$, respectively. $L_{l}$ and $L_{u}$ : lower and upper $95 \%$ confidence limits for $b^{\prime}$. r: correlation coefficient. $r^{2}$ : coefficient of determination. $\mathrm{p}$ : significance of the regression (Model I). $\mathrm{n}$ : number of data points

\begin{tabular}{|c|c|c|c|c|c|c|c|c|c|c|c|c|}
\hline y & $x$ & $a$ & $\mathrm{SE}_{a}$ & $b$ & $\mathrm{SE}_{b}$ & $b^{\prime}$ & $\mathrm{L}_{\mathrm{l}}$ & $\mathrm{L}_{\mathrm{u}}$ & $\mathrm{r}$ & $r^{2}$ & $\mathrm{p}$ & $\mathrm{n}$ \\
\hline $\log \mathrm{rDOC}$ & $\log c h l a$ & -1.278 & 0.070 & 0.603 & 0.189 & 1.069 & 0.677 & 1.461 & 0.564 & 0.318 & 0.004 & 24 \\
\hline $\log \mathrm{rDOC}$ & $\log \mathrm{PPOC}$ & 0.956 & 0.088 & 0.425 & 0.090 & 0.587 & 0.408 & 0.781 & 0.724 & 0.497 & 0.000 & 24 \\
\hline $\log \mathrm{rDON}$ & log Chl-a & 1.081 & 0.053 & 0.372 & 0.162 & 1.014 & 0.685 & 1.342 & 0.367 & 0.135 & 0.028 & 36 \\
\hline $\log \mathrm{rDON}$ & $\log \mathrm{PON}$ & 1.109 & 0.057 & 0.173 & 0.189 & 1.109 & 0.725 & 1.493 & 0.156 & 0.024 & 0.365 & 36 \\
\hline $\log \mathrm{rDON}$ & $\log \rho \mathrm{NH}_{4}$ & 0.407 & 0.192 & 0.418 & 0.113 & 0.778 & 0.549 & 1.008 & 0.537 & 0.289 & 0.001 & 36 \\
\hline $\log \mathrm{rDON}$ & $\log$ PPOC & 1.245 & 0.081 & 0.207 & 0.087 & 0.548 & 0.371 & 0.724 & 0.378 & 0.143 & 0.023 & 36 \\
\hline $\log \mathrm{rDON}$ & $\log \mathrm{rDOC}$ & 1.418 & 0.217 & 0.259 & 0.165 & 0.814 & 0.472 & 1.157 & 0.318 & 0.101 & 0.130 & 24 \\
\hline $\log \mathrm{PER}_{\mathrm{DOC}}$ & $\log \mathrm{PER}_{\mathrm{DON}}$ & 0.222 & 0.345 & 0.823 & 0.257 & 1.319 & 0.774 & 1.864 & 0.624 & 0.389 & 0.006 & 24 \\
\hline
\end{tabular}


Table 2. Parameters of regression lines between $\mathrm{C}$ and $\mathrm{N}$ uptake or release rates using euphotic zone integrated values. Equations were computed using both Model I and Model II regression models (Sokal \& Rohlf 1981): $y=b x$. $b^{\prime}$ : slope of Model II regression. $x$ : independent variable. $y$ : independent variable. $\mathrm{SE}_{b}$ : standard error of the slope. $\mathrm{L}_{\mathrm{l}}$ and $\mathrm{L}_{\mathrm{u}}$ : lower and upper $95 \%$ confidence limits for $b^{\prime}$. r: correlation coefficient. $r^{2}$ : coefficient of determination. p: significance of the regression (Model I). n: number of data points

\begin{tabular}{|lcccccccccc|}
\hline$y$ & $x$ & $b$ & $\mathrm{SE}_{b}$ & $b^{\prime}$ & $\mathrm{L}_{\mathrm{l}}$ & $\mathrm{L}_{\mathrm{u}}$ & $\mathrm{r}$ & $\mathrm{r}^{2}$ & $\mathrm{p}$ & $\mathrm{n}$ \\
\hline PPOC & $\rho \mathrm{NH}_{4}$ & 6.836 & 0.430 & 7.941 & 6.025 & 7.941 & 0.979 & 0.958 & $<0.001$ & 12 \\
rDOC & $\mathrm{rDON}$ & 6.921 & 1.023 & 7.434 & 4.391 & 9.937 & 0.931 & 0.867 & $<0.001$ & 8 \\
PPOC + rDOC & $\rho \mathrm{NH}_{4}+\mathrm{rDON}$ & 6.996 & 0.542 & 7.139 & 5.813 & 8.465 & 0.980 & 0.960 & $<0.001$ & 8 \\
\hline
\end{tabular}

which indicates that, on average, the fraction of gross $\mathrm{C}$ and $\mathrm{N}$ uptake released as dissolved substrates was equivalent.

We reconstructed the seasonal pattern of uptake and release in the euphotic zone by using the measured values and estimating missing rDOC values with the equations in Table 2 . The general coincidence of maximum and minimum values, already noted for volumetric rates, was more evident, PER values accounting for a small fraction of total uptake (Fig. 8). The C:N ratios of uptake rates were linearly correlated and the slope of the regression line was
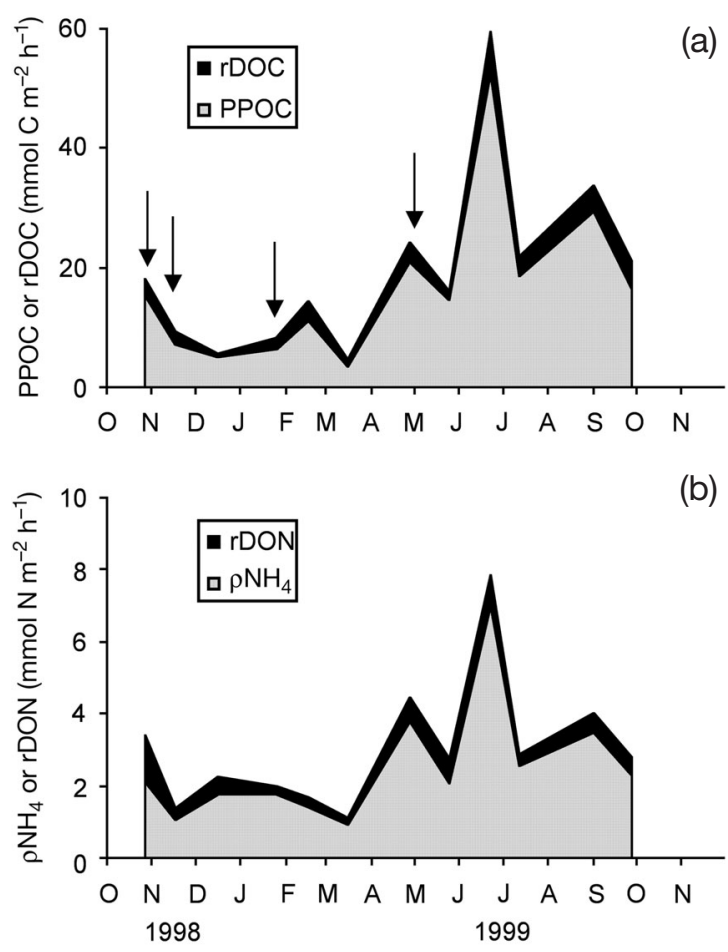

Fig. 8. Variations of euphotic zone integrated values of (a) particulate organic carbon incorporation (PPOC) and dissolved organic carbon release (rDOC), and (b) ammonium uptake $\left(\rho \mathrm{NH}_{4}\right)$ and release of dissolved organic nitrogen $(\mathrm{rDON})$. Arrows indicate sampling dates where missing rDOC values were estimated from PPOC using the appropriate equation from Table 1 close to the Redfield value (Fig. 9). In this way, the $95 \%$ confidence limits of the Model II regression slope of both net (PPOC and $\rho \mathrm{NH}_{4}$ ) and gross (PPOC $+\mathrm{rDOC}$ and $\rho \mathrm{NH}_{4}+\mathrm{rDON}$ ) uptake rates included the value 6.6 (Table 2). In the latter case, the slopes of the lines obtained using only the concurrent measurements of DOC and DON, and those including estimates of DOC from PPOC were equivalent (ANOVA, $\mathrm{p}>0.05)$. Also, $\mathrm{C}$ and $\mathrm{N}$ release rates were related by a factor close to the Redfield value (Fig. 9, Table 2), but in this case the relationship was significant only when the estimated rDOC values were excluded from the computation. Annual average $( \pm \mathrm{SE})$ PER values for integrated $\mathrm{C}$ and $\mathrm{N}$ rates were similar (15.1 \pm 2.5 and $22.8 \pm 3.9 \%$ for $\mathrm{C}$ and $\mathrm{N}$, respectively).

\section{DISCUSSION}

\section{Seasonal variations}

Contrasting seasons of high and low plankton productivity alternate in the waters off northwest Spain under the influence of the coastal upwelling (e.g. Casas et al. 1997, Bode et al. 1998, 2004, AlvarezSalgado et al. 2001, 2002, Teira et al. 2001a, 2003b). Stocks of dissolved organic matter increased over the shelf during the high primary production period in spring and summer, when upwelling events were frequent (Doval et al. 1997, Alvarez-Salgado et al. 1999, 2001, Varela et al. 2003a,b). Such an increase was primarily caused by the enhanced production of phytoplankton. In this way, measurements of short-term release rates of both DOC (Teira et al. 2001a, Morán et al. 2002a,b, Teira et al. 2003b) and DON (Varela et al. 2003b) showed a close relationship with the production of particulate matter during upwelling conditions. However, the fraction of recently fixed $\mathrm{C}$ or $\mathrm{N}$ that is released as DOC or DON was not constant, and PER values from the low productivity winter and autumn period were higher than those from the upwelling period (Teira et al. 2001a, Morán et al. 2002a,b, Teira et al. 2003b, Varela et al. 2003b). 

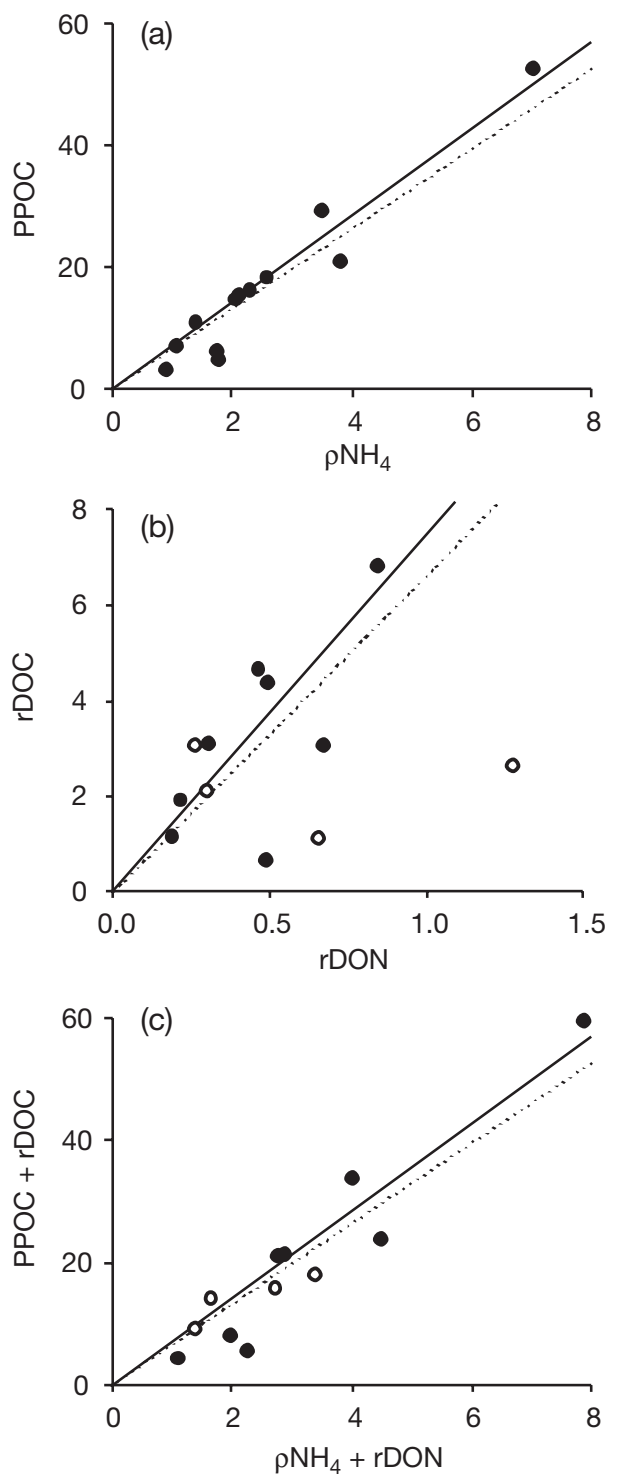

Fig. 9. Plot of $\mathrm{C}: \mathrm{N}$ molar ratios computed using euphotic-zone integrated values of (a) PPOC and $\mathrm{PNH}_{4}$, (b) rDOC and rDON, or (c) $\mathrm{PPOC}+\mathrm{rDOC}$ and $\rho \mathrm{NH}_{4}+\mathrm{rDON}$. All rates were in $\mathrm{mmol} \mathrm{m}{ }^{-2} \mathrm{~h}^{-1}$. The Redfield ratio (6.6) is indicated by a dashed line. Continuous line indicates the Model II regression line (see Table 2). (0) Points where rDOC was estimated from PPOC. Such points were not considered when computing the regression lines displayed

Our results gained from our station off A Coruña fit well with the described seasonal variation pattern, as most of the measured increase in DON stocks occurred during summertime, when PPOC and $\rho \mathrm{NH}_{4}{ }^{+}$also peaked. Interestingly, the monthly variability of hourly production and release rates of $\mathrm{N}$ was higher than the variability of the DON stock. Production and release rates were driven by episodic upwelling events causing nutrient enrichment of surface waters (e.g. June
1999). However, not all the produced organic matter (either particulate or dissolved) accumulated at the study site. Studies with sediment traps at the same site (Bode et al. 1998, Teira et al. 2003b) revealed that up to $80 \%$ of PPOC was exported as sinking particles. In addition, DOC losses were on average ca. $30 \%$ of total carbon uptake (Teira et al. 2003b), a value similar to those found in nearby areas (Teira et al. 2001a, Varela et al. 2003a). Hydrodynamic processes, such as upwelling filaments injecting coastal waters into the ocean (e.g. Alvarez-Salgado et al. 2001), are able to transport a significant fraction of organic matter out of the production sites, thus fuelling food webs of the nearby ocean (Barbosa et al. 2001). During active upwelling, particle sedimentation near the coast accounts for a small fraction of total carbon export (Bode et al. 1998, Schmidt et al. 2002, Teira et al. 2003b). Nevertheless, dissolved organic matter accumulation near the coast during the productive upwelling season was reported by studies of DOC and DON concentrations (Doval et al. 1997, Alvarez-Salgado et al. 1999, 2001, Bode et al. 2001, Varela et al. 2003a,b) and short-term release rates (Teira et al. 2001a, 2003b, Varela et al. 2003b). Such accumulations are caused by the relatively low bacterial consumption rates of DOC (Morán et al. 2002a, Teira et al. 2003b, Varela et al. 2003a) during the productive upwelling season, which translates into a time lag between DOC release and consumption, as reported for other temperate marine ecosystems (e.g. Serret et al. 1999). Although DOC concentrations were not measured in our study, such a time lag is supported by the measured DON accumulation during the spring-summer period.

\section{Vertical variability}

The differential effect of physical and biological factors in the measured uptake and release rates may be invoked as the cause of vertical maxima in the water column. For instance, uptake processes as PPOC and $\rho \mathrm{NH}_{4}{ }^{+}$peaked generally near the surface, as they were dependent of light. Also, rDOC, which was closely linked to PPOC, reached maximum values near the surface. In contrast, rDON and the relative release of both DOC and DON often showed maximum values near the base of the euphotic zone. These deep maxima suggest that biological processes, such as direct excretion of dissolved substrates by inefficient, energy-limited cells or grazing would be involved. While the light dependence of PPOC was obvious, high light levels are not necessary for $\mathrm{\rho NH}_{4}{ }^{+}$, as the uptake and assimilation of ammonium has lower energetic demands than those of nitrate (Syrett 1981). Experimental studies showed than $\rho \mathrm{NH}_{4}{ }^{+}$is less light dependent 
than nitrate uptake (e.g. Koike et al. 1986). Still, high $\rho \mathrm{NH}_{4}{ }^{+}$is expected to occur in parallel with high PPOC rates when most of the nitrogen used for primary production is provided by ammonium (Harrison 1990). In this way, PPOC in the study area was largely dependent on regenerated nitrogen sources (as ammonium and urea), despite the occasional upwelling pulses of nitrate (Alvarez-Salgado et al. 2002, Bode et al. 2004).

An increase in $\mathrm{rDON}$, and in the relative amount of released organic matter at low light levels, may be explained by physiological mechanisms. Loss of dissolved organic substances has been related to the excretion of carbohydrates by light or nutrient limited phytoplankton (Søndergaard et al. 2000). Near the lower limit of the euphotic layer, nutrient assimilation may be limited by the availability of light even when nutrient concentrations were higher that in surface layers, as indicated by the incomplete assimilation of nitrate (Planas et al. 1999). Active excretion of recent photosynthates may help to maintain concentration gradients across the cell membrane (e.g. Carlson 2002 and references therein). The taxonomic and size composition of phytoplankton affects PER values, which increase when small cells dominate (e.g. Morán et al. 2002a). However, at the study site most of the variation in phytoplankton composition was seasonal, with relatively little vertical variability (Casas et al. 1999). More important for the increase of PER values with depth would be the losses caused by grazing. Studies in other areas have shown that sloppy feeding by mesozooplankton would release up to half of DOC (Nagata 2000), while DON release by protozoan grazers would even exceed direct release by phytoplankton (Hasegawa et al. 2000b). Indirect evidence of the importance of grazers in the study area comes from the often-cited association between the deep chlorophyll maximum and the vertical abundance or biomass maximum of microzooplankton (Valdés et al. 1992, Quevedo \& Anadón 2000). In addition, Fileman \& Burkill (2001) showed a close association between microzooplankton grazing rates and chlorophyll concentrations in the Galician upwelling.

In any case, our results show that, while carbon uptake and rDOC was often in excess when compared with the Redfield ratio in surface layers, the converse situation was found at the base of the euphotic zone. Such relative excess of nitrogen uptake and rDON was measured during most of winter and spring (Fig. 6), when nutrient concentrations were high but the available radiation for photosynthesis and photoperiod were low. The lack of coupling between the rates of $\mathrm{C}$ and $\mathrm{N}$ at both limits of the euphotic zone further stress the importance of light for carbon production and release by phytoplankton, while nitrogen rates would depend more on trophic factors.

\section{Carbon and nitrogen coupling}

In this study, we have used ammonium as the only source for measuring $\mathrm{N}$ uptake and release, but primary producers can also use nitrate, nitrite and even DON sources (as urea). Moreover, in an upwelling environment as the study site, nitrate would be expected to be a significant source for primary production (Alvarez-Salgado et al. 2002). However, the results of previous measurements with ${ }^{15} \mathrm{~N}$ at the study site indicate that nitrate uptake is only important during the intermittent upwelling events, while most of primary production is fuelled by regenerated nitrogen (Bode et al. 2004). In addition, the use of ammonium allows for a comparative study over the year because its concentration in the euphotic zone varies generally between 0.2 and $1 \mu \mathrm{M}$, thus minimizing the effect of substrate concentration on uptake rates (Syrett 1981). In contrast, nitrate concentrations varied between $<0.2$ and $>10 \mu \mathrm{M}$ in the euphotic zone (Bode et al. 2004). Our results of rDON are, thus, minimum estimates of total DON release at the study site, and short-term rates would likely double during upwelling when taking into account other nitrogen sources, such as nitrate. Other studies showed that rDON from nitrate uptake may equal (Slawyk et al. 1998) or even exceed rDON derived from ammonium (Bronk \& Ward 1999).

Both DOC and DON were released at rates linearly related to uptake, and particularly to PPOC, but PER values decreased with the increase in uptake. Such an inverse relationship between PER and uptake was well described for DOC (Teira et al. 2001a,b, Morán et al. 2002a,b, Teira et al. 2003b) but the data presented here are the first evidence for DON release. As a consequence, there is a reduction in the relative rates of organic matter release with increasing productivity. Furthermore, our results indicate that, while volumetric values of both rates can be very variable (Fig. 6), DOC and DON were released at rates close to the Redfield value when considering euphotic-zone integrated values (Table 2). This apparent contradiction may be due to the differential participation of physiological or trophic mechanisms in the release of dissolved substrates at different depths and seasons, as discussed above, while considering the whole euphotic zone and all seasons, the release of DOC and DON reflect the elemental composition of phytoplankton. Thus, shortterm released organic matter in the study area derives mainly from phytoplankton, whatever the liberation processes implied. In contrast, a previous study of 4 selected oceanographic situations in coastal and oceanic waters off the southern shelf of Galicia found a low correlation between DOC and DON release, and the corresponding slope of the regression line was far from the Redfield value (Varela et al. 2003b). Also, C:N 
ratios of DOC and DON stocks are often much higher than the Redfield ratio (Doval et al. 1997, AlvarezSalgado et al. 1999, 2001).

However, it must be taken into account that any relative excess of DOC versus DON may occur not only because of an excess of carbohydrate synthesis by phytoplankton when nitrogen is scarce (e.g. Søndergaard et al. 2000), but also because the planktonic bacteria may be unable to consume DOC (Williams 1995). Several studies have shown that bacteria compete for inorganic nitrogen with phytoplankton, but at the same time bacteria can use DON to met their $\mathrm{N}$ requirements (Kirchman 2000). Therefore, under nitrogen limiting conditions, bacterial activity may increase $\mathrm{C}: \mathrm{N}$ ratios of dissolved organic matter by decreasing inorganic nitrogen availability for phytoplankton (thus increasing rDOC as phytoplankton cells release carbohydrates) and by consuming DON. This would explain the case in shelf and oceanic waters where high $C: N$ ratios of dissolved matter would reflect nitrogen limiting conditions after upwelling (Varela et al. 2003b), when bacterial activity was also low (Barbosa et al. 2001). When nitrogen was not at limiting concentrations, C:N ratios of released DOM were low due to the accumulation of nitrogen-rich DON, as described for selected situations in Chesapeake Bay (Bronk et al. 1998, Bronk 2002). At the study site, however, both upwelling activity and in situ regeneration of inorganic nitrogen would be enough to maintain both phytoplankton and microbial populations (Bode et al. 2004), and this would be reflected in average C:N values of both particulate and recently released dissolved organic matter close to the Redfield value. In addition, the mismatch between the average DOC:DON ratio in recently released organic matter and the average POC:PON value suggest that nitrate-derived DON would be of low importance in the studied system. Microbial processes, such as the conversion of labile DON substrates into refractory ones (Ogawa et al. 2001), would cause the observed excess of $C$ relative to $\mathrm{N}$ in dissolved organic matter stocks (Doval et al. 1997 , 1999, Alvarez-Salgado et al. 1999, 2001).

This study has shown that short-term release of DOC and DON near the coast is closely dependent on uptake rates. As the causative mechanisms of the release of $\mathrm{C}$ and $\mathrm{N}$ behave differently in relation to irradiance, rDOC is generally highest near the surface, while rDON reachs its maximum near the base of the euphotic zone. This differential response to light produces DOC:DON ratios at both high and low irradiances that are far from the Redfield ratio. However, when taking into account euphotic zone integrated rates, both $\mathrm{C}$ and $\mathrm{N}$ are taken up and released at ratios proportional to the elemental composition of particulate organic matter, at least when rates were averaged over the annual cycle. These results suggest that most of the organic matter available for microbial plankton derives from phytoplankton (Bronk 2002), which in turn takes up most of their required nitrogen from regenerated sources. As a result, as shown by Teira et al. (2003b), an average of $57 \%$ of gross primary production at this site is processed by the microbial community, while only during upwelling events may equivalent amounts of carbon production be available to higher trophic levels. The present study supports the hypothesis that rapid recycling of organic matter, as expected in oligotrophic waters, also occur in coastal, seasonally productive waters, thus allowing the sustaining of a relatively high biomass of plankton in periods of low external nutrient inputs.

Acknowledgements. We are indebted to the crew of RV 'Lura' who facilitated the collection of samples, and to the technical assistance of B. Castro (nitrogen production), J. Lorenzo (carbon production), C. Carballo (inorganic nitrogen concentrations), M. Fermoso (CHN analysis) and M. Lema (stable isotopes). M.M.V. and E.T. were supported by PFPI fellowships of the Ministerio de Ciencia y Tecnología (Spain). The comments by an anonymous referee to a first version of the manuscript were much appreciated. This work was partially funded by projects IEO-1007 (Instituto Español de Oceanografía, Spain), XUGA-1030213-98 (Xunta de Galicia, Spain) and OMEX-II Phase-II (MAST3-CT97-0076, European Union). We acknowledge the support of J. Abalde and A. Cid (Universidade da Coruña, Spain) during the XUGA project. This is contribution number 193 of the IEO-1007 project.

\section{LITERATURE CITED}

Agustí SP, Satta MP, Mura P, Benavent E (1998) Dissolved esterase activity as a tracer of phytoplankton lysis rates in the NW Mediterranean. Limnol Oceanogr 43:1836-1849

Alvarez-Salgado XA, Doval MD, Pérez FF (1999) Dissolved organic matter in shelf waters off the Ria de Vigo (NW Iberian upwelling system). J Mar Syst 18:383-394

Alvarez-Salgado XA, Doval MD, Borges AV, Joint I, Frankignoulle M, Woodward EMS, Figueiras FG (2001) Off-shelf fluxes of labile materials by an upwelling filament in the NW Iberian upwelling system. Prog Oceanogr 51:321-337

Alvarez-Salgado XA, Beloso S, Joint I, Nogueira E and 6 others (2002) New production of the NW Iberian shelf during the upwelling season over the period 1982-1999. DeepSea Res Part I 49:1725-1739

Barbosa AB, Galvao HM, Mendes PA, Alvarez-Salgado XA, Figueiras FG, Joint I (2001) Short-term variability of heterotrophic bacterioplankton during upwelling off the NW Iberian margin. Prog Oceanogr 51:339-359

Berger WH, Smetacek VS, Wefer G (1989) Ocean productivity and paleoproductivity - an overview. In: Berger $\mathrm{WH}_{\text {, }}$ Smetacek VS, Wefer G (eds) Productivity of the ocean: present and past. J Wiley \& Sons, New York, p 1-34

Bode A, Varela M, Barquero S, Alvarez-Ossorio MT, González N (1998) Preliminary studies on the export of organic matter during phytoplankton blooms off La Coruña (North Western Spain). J Mar Biol Assoc UK 78:1-15

Bode A, Varela M, Canle M, González N (2001) Dissolved and particulate organic nitrogen in shelf waters of northern 
Spain during spring. Mar Ecol Prog Ser 214:43-5

Bode A, Barquero S, González N, Alvarez-Ossorio MT, Varela M (2004) Contribution of heterotrophic plankton to nitrogen regeneration in the upwelling ecosystem of A Coruña (NW Spain). J Plankton Res 26:1-18

Bronk DA (2002) Dynamics of DON. In: Hansell DA, Carlson CA (eds) Biogeochemistry of marine dissolved organic matter. Elsevier Science, Amsterdam, p 153-247

Bronk DA, Glibert PM (1991) A ${ }^{15} \mathrm{~N}$ tracer method for the measurement of dissolved organic nitrogen release by phytoplankton. Mar Ecol Prog Ser 77:171-182

Bronk DA, Ward BB (1999) Gross and net nitrogen uptake and DON release in the euphotic zone of Monterey Bay, California. Limnol Oceanogr 44:573-585

Bronk DA, Ward BB (2000) Magnitude of dissolved organic nitrogen release relative to gross nitrogen uptake in marine systems. Limnol Oceanogr 45:1879-188

Bronk DA, Glibert PM, Malone TC, Banahan S, Sahlsten E (1998) Inorganic and organic nitrogen cycling in Chesapeake Bay: autotrophic versus heterotrophic processes and relationships to carbon flux. Aquat Microb Ecol 15: 177-189

Carlson CA (2002) Production and removal processes. In: Hansell DA, Carlson CA (eds) Biogeochemistry of marine dissolved organic matter. Elsevier Science, Amsterdam, p 91-151

Casas B, Varela M, Canle M, González N, Bode A (1997) Seasonal variations of nutrients, seston and phytoplankton, and upwelling intensity off La Coruña (NW Spain). Estuar Coast Shelf Sci 44:767-778

Casas B, Varela M, Bode A (1999) Seasonal succession of phytoplankton species on the coast of A Coruña (Galicia, northwest Spain). Bol Inst Esp Oceanogr 15:413-429

Doval MD, Alvarez-Salgado XA, Pérez FF (1997) Dissolved organic matter in a temperate embayment affected by coastal upwelling. Mar Ecol Prog Ser 157:21-37

Doval MD, Pérez FF, Berdalet E (1999) Dissolved and particulate organic carbon and nitrogen in the Northwestern Mediterranean. Deep-Sea Res Part I 46:511-527

Fileman E, Burkill P (2001) The herbivorous impact of microzooplankton during two short-term Lagrangian experiments off the NW coast of Galicia in summer 1998. Prog Oceanogr 51:361-383

Glibert PM (1988) Primary productivity and pelagic nitrogen cycling. In: Blackburn TH, Sorensen JE (eds) Nitrogen cycling in coastal marine environments. J Wiley \& Sons, New York, p 3-31

Grasshoff K, Ehrhardt M, Kremling K (1983) Methods of seawater analysis, 2nd edn. Verlag Chemie, Weinheim

Harrison WG (1990) Nitrogen utilization in chlorophyll and primary productivity maximum layers: an analysis based on the f-ratio. Mar Ecol Prog Ser 60:85-90

Hasegawa T, Koike I, Mukai H (2000a) Release of dissolved organic nitrogen by size-fractionated natural planktonic assemblages in coastal waters. Mar Ecol Prog Ser 198: 43-49

Hasegawa T, Koike I, Mukai H (2000b) Estimation of dissolved organic nitrogen release by micrograzers in natural planktonic assemblages. Plankton Biol Ecol 47:23-30

Kirchman DL (2000) Uptake and regeneration of inorganic nutrients by marine heterotrophic bacteria. In: Kirchman DL (ed) Microbial ecology of the oceans. Wiley-Liss, New York, p 261-288

Koike I, Holm-Hansen O, Biggs DC (1986) Inorganic nitrogen metabolism by Antarctic phytoplankton with special reference to ammonium cycling. Mar Ecol Prog Ser 30:105-116

Legendre L, Le Fèvre J (1995) Microbial food webs and the export of biogenic carbon in oceans. Aquat Microb Ecol 9: 69-77

Morán XAG, Estrada M, Gasol JM, Pedros-Alió C (2002a) Dissolved primary production and the strength of phytoplankton-bacterioplankton coupling in contrasting marine regions. Microb Ecol 44:217-223

Morán XAG, Gasol JM, Pedrós-Alió C, Estrada M (2002b) Partitioning of phytoplanktonic organic carbon production along a coastal-offshore gradient in the NE Atlantic during different hydrographic regimes. Aquat Microb Ecol 29:239-252

Nagata T (2000) Production mechanisms of dissolved organic matter. In: Kirchman DL (ed) Microbial ecology of the oceans. Wiley-Liss, New York, p 121-152

Ogawa H, Tanoue E (2003) Dissolved organic matter in oceanic waters. J Oceanogr 59:129-147

Ogawa H, Amagai Y, Koike I, Kaiser K, Benner R (2001) Production of refractory dissolved organic matter by bacteria. Science 292:917-920

Parsons TR, Maita Y, Lalli CM (1984) A manual of chemical and biological methods for seawater analysis. Pergamon Press, Oxford

Planas D, Agustí S, Duarte CM, Granata TC, Merino M (1999) Nitrate uptake and diffusive nitrate supply in the Central Atlantic. Limnol Oceanogr 44:116-126

Quevedo M, Anadón R (2000) Spring microzooplankton composition, biomass and potential grazing in the Central Cantabrian coast (southern Bay of Biscay). Oceanol Acta 23:297-309

Redfield AC, Ketchum BH, Richards FA (1963) The influence of organisms on the composition of sea-water. In: Hill MN (ed) The sea, Vol 2. Wiley Interscience, New York, p 26-79

Schmidt S, Chou L, Hall IR (2002) Particle residence times in surface waters over the north-western Iberian Margin: comparison of pre-upwelling and winter periods. J Mar Syst 32:3-11

Serret P, Fernandez E, Sostres JA, Anadón R (1999) Seasonal compensation of microbial production and respiration in a temperate sea. Mar Ecol Prog Ser 187:43-57

Slawyk G, Raimbault P (1995) Simple procedure for simultaneous recovery of dissolved inorganic and organic nitrogen in ${ }^{15} \mathrm{~N}$ tracer experiments and improving the isotopic mass balance. Mar Ecol Prog Ser 124:289-299

Slawyk G, Raimbault P, Garcia N (1998) Measuring gross uptake of ${ }^{15} \mathrm{~N}$-labeled nitrogen by marine phytoplankton without particulate matter collection: Evidence of low ${ }^{15} \mathrm{~N}$ losses to the dissolved organic nitrogen pool. Limnol Oceanogr 43:1734-1739

Slawyk G, Raimbault P, Garcia N (2000) Use of ${ }^{15} \mathrm{~N}$ to measure dissolved organic nitrogen release by marine phytoplankton. Limnol Oceanogr 45:1884-1886

Sokal RR, Rohlf FJ (1981) Biometry, 2nd edn. WH Freeman, San Francisco

Søndergaard M, Williams PJlB, Cauwet G, Riemann B, Robinson C, Terzic S, Woodward EMS, Worm J (2000) Net accumulation and flux of dissolved organic carbon and dissolved organic nitrogen in marine plankton communities. Limnol Oceanogr 45:1097-1111

Syrett PJ (1981) Nitrogen metabolism of microalgae. Can Bull Fish Aquat Sci 210:182-210

Teira E, Serret P, Fernández E (2001a) Phytoplankton size structure, particulate and dissolved carbon production and oxygen fluxes through microbial communities in the NW Iberian coastal transition zone. Mar Ecol Prog Ser 219: 65-8

Teira E, Pazó MJ, Serret P, Fernández E (2001b) Dissolved organic carbon (DOC) production by microbial popula- 
tions in the Atlantic Ocean. Limnol Oceanogr 46: 1370-1377

Teira E, Pazó MJ, Quevedo M, Fuentes MV, Niell FX, Fernández E (2003a) Rates of dissolved organic carbon production and bacterial activity in the eastern North Atlantic Subtropical Gyre during summer. Mar Ecol Prog Ser 249:53-67

Teira E, Abalde J, Alvarez-Ossorio MT, Bode A and 7 others (2003b) Plankton carbon budget in a coastal wind-driven upwelling station off A Coruña (NW Iberian Peninsula). Mar Ecol Prog Ser 265:31-43

Valdés F, Alvarez-Ossorio MT, Miranda A (1992) Composición y abundancia del microzooplancton en la plataforma continental gallega. Thalassas 10:107-114

Valencia J, Abalde J, Bode A, Cid A and 5 others (2003) Variations in planktonic bacterial biomass and production, and phytoplankton blooms off A Coruña (NW Spain). Sci Mar 67:143-157

Editorial responsibility: Frede Thingstad,

Bergen, Norway
Varela MM, Bode A, González N, Rodríguez C, Varela M (2003a) Fate of organic matter in the Ría de Ferrol (Galicia, NW Spain): uptake by pelagic bacteria versus particle sedimentation. Acta Oecologica 24:S77-S86

Varela MM, Barquero S, Bode A, Fernández E, González N, Teira E (2003b) Microplanktonic regeneration of ammonium and dissolved organic nitrogen in the upwelling area of the NW of Spain: relationships with dissolved organic carbon production and phytoplankton size-structure. J Plankton Res 25:719-736

Vidal M, Duarte CM, Agustí S (1999) Dissolved organic nitrogen and phosphorus pools and fluxes in the central Atlantic Ocean. Limnol Oceanogr 44:106-115

Williams PJIB (1995) Evidence for the seasonal accumulation of carbon-rich dissolved organic material, its scale in comparison with changes in particulate material and the consequent effect on net $\mathrm{C} / \mathrm{N}$ assimilation ratios. Mar Chem 51:17-29

Submitted: April 6, 2004; Accepted: July 12, 2004

Proofs received from author(s): October 8, 2004 